\title{
Physiological quality of dynamically cooled and stored soybean seeds ${ }^{1}$
}

\author{
Jacson Zuchi²*, José de Barros França-Neto ${ }^{3}$, Carlos Sigueyuki Sediyama ${ }^{4}$, \\ Adílio Flauzino de Lacerda Filho ${ }^{5}$, Múcio Silva Reis ${ }^{4}$
}

\begin{abstract}
Storage is an important step in the production of soybean seeds, mainly in tropical regions, where high temperatures can drastically reduce seed quality. The storage at cooler temperatures may be a feasible alternative to preserve seed quality during storage. The objective of this study was to evaluate the physiological quality of soybean seeds artificially cooled by a dynamic process and stored in an environment, with non controlled temperature and relativity humidity. Two seed lots of cultivars Monsoy 8757, TMG 115 RR and BRS Valiosa RR were used. After processing and during packaging the seeds were cooled to $18{ }^{\circ} \mathrm{C}$ by a dynamic process. Seed samples were collected after 0,60 and 120 days of storage, using the following parameters germination, accelerated aging, seedling emergence in sand, speed of emergence index, electrical conductivity, tetrazolium and seed health. Although soybean seeds artificially cooled by the dynamic method may have slightly superior performance in maintaining physiological quality during storage in non-refrigerated warehouse, for lots of high physiological quality, these advantages are not observed.
\end{abstract}

Index terms: Glycine max, cooling, storability, vigor.

\section{Qualidade fisiológica de sementes de soja resfriadas dinamicamente e armazenadas}

\begin{abstract}
RESUMO - O armazenamento é uma etapa importante na produção de sementes de soja, principalmente em regiões tropicais, onde as temperaturas elevadas podem reduzir drasticamente a qualidade das sementes. A armazenagem em temperaturas mais amenas pode ser uma alternativa para melhor preservar a qualidade das sementes durante o armazenamento. O objetivo do trabalho foi avaliar a qualidade fisiológica de sementes de soja resfriadas artificialmente por um processo dinâmico e armazenadas em ambiente sem controle da temperatura e umidade relativa do ar. Dois lotes de sementes das cultivares Monsoy 8757, TMG 115 RR e BRS Valiosa RR, foram utilizados. Após o beneficiamento, durante a operação de ensaque, as sementes foram resfriadas a $18{ }^{\circ} \mathrm{C}$ por processo dinâmico. Amostras de sementes foram coletadas após 0,60 e 120 dias do armazenamento, sendo avaliados os parâmetros: germinação, envelhecimento acelerado, emergência de plântulas em areia, índice de velocidade de emergência, condutividade elétrica, tetrazólio e sanidade. Embora as sementes de soja resfriadas artificialmente pelo método dinâmico apresentem desempenho ligeiramente superior na manutenção da qualidade fisiológica durante o armazenamento sem refrigeração, para lotes de elevado desempenho fisiológico, vantagens relacionadas ao resfriamento das sementes não são observadas.
\end{abstract}

Termos para indexação: Glycine max, resfriamento, armazenabilidade, vigor.

\section{Introduction}

Storage is an important step in the production of soybeans, because of the high temperature and relative humidity conditions in some regions of Brazil. The soybean seed, Glycine max (L.) Merr., is considered to be short-lived and unfavorable storage

${ }^{1}$ Submitted on 02/14/2013. Accepted for publication on 06/02/2013.

${ }^{2}$ Fundação Estadual de Pesquisa Agropecuária - Fepagro, Caixa Postal 20, 95200-970- Vacaria, RS, Brasil.

${ }^{3}$ Tecnologia de Sementes da Embrapa Soja, Caixa Postal 231, 86001-970 -

Londrina, PR, Brasil. conditions accelerate its deterioration (Popinigis, 1985). Therefore, the study of problems related to the storage of seeds and grains is permanent (Bragantini, 2005).

During the storage period, seed quality cannot be improved, however, it can be preserved with the use of appropriate conditions of humidity and temperature of

${ }^{4}$ Departamento de Fitotecnia, Universidade Federal de Viçosa - UFV, 36570-000 - Viçosa, MG, Brasil.

${ }^{5}$ Departamento de Engenharia Agrícola, Universidade Federal de Viçosa- UFV, 36570-000- Viçosa, MG, Brasil.

*Corresponding author < jacson-zuchi@fepagro.rs.gov.br> 
the environment (Carvalho and Nakagawa, 2000; Ferreira and Borguetti, 2004), enabling lower seed metabolism and reducing the attack of pathogenic microorganisms, thereby minimizing the loss of quality.

The benefits of using artificial cooling during processing are still not very clear. Demito and Afonso (2009) found that artificially cooled soybean seeds, when compared to uncooled seeds, maintained the germination throughout the storage period due to their better storage conditions. However, Cunha et al. (2009) state that the deterioration can be intensified by extending the storage period, even under refrigeration. Carvalho and Silva (1994) noted that artificial cooling maintained the physiological quality of soybean seeds during storage, but this cannot happen if the seed has an initial moisture content of $14 \%$ and are stored at the top of the stack (Cardoso et al., 2004).

During the storage phase of soybean seeds, the damages that contribute the most to reduction in germination and vigor are damages caused by moisture and mechanical damage (Moreano et al., 2011). According to these authors, these types of damage evolve significantly during storage, resulting in serious reductions in quality. Since a lower temperature during storage reduces the metabolism of seeds (Demito and Afonso, 2009), the use of lower temperatures can reduce the development of these types of damage to the seeds.

Regarding this aspect, mechanical damage occurring in the seeds can be classified into two categories: immediate and latent. França-Neto et al. (1998) mentioned that there is evidence that the latter is what evolves the most during storage and this evolution can be influenced by room temperature and relative humidity $(\mathrm{RH})$ conditions.

Moreira (1994) and Demito and Afonso (2009) reported that cooling may decrease the water content in the seeds. Harrington (1960) established some assumptions regarding the preservation of the quality of orthodox seeds during storage, which remain valid today: the storage period of seeds doubles for each $1 \%$ reduction in water content, in moisture content ranging from $6 \%$ to $20 \%$, and the storage period of seed doubles for every $5.5^{\circ} \mathrm{C}\left(10^{\circ} \mathrm{F}\right)$ reduction in storage temperature within the range from $4.4^{\circ} \mathrm{C}$ to $37.8^{\circ} \mathrm{C}\left(40{ }^{\circ} \mathrm{F}\right.$ to $\left.100{ }^{\circ} \mathrm{F}\right)$. Therefore, based on this report and those presented previously, it is evident that the seed storage under conditions of lower temperatures has advantages in preserving their germination and vigor.

In Brazil, the technology of artificial cooling has been studied since the $1980 \mathrm{~s}$, but there is little scientific information published on the subject. The cooling of the seeds may be held in warehouses with refrigeration equipment, associated or not with dehumidifiers to also control the RH of the air. The most routinely used temperatures in these warehouses range from $10{ }^{\circ} \mathrm{C}$ to $18{ }^{\circ} \mathrm{C}$, usually associated with $\mathrm{RH}$ conditions of $50 \%$ to $60 \%$.

Currently, there is also a system of dynamic seed cooling, used in the country's Central-West Region, for the better preservation of the quality of soybean and rice seeds. This technology consists of injecting cold air into the mass of seeds, to reduce the temperature and hence the deterioration of soybean seeds, in order to preserve their quality in a conventional storage without temperature control. The dynamic cooling of soybean seeds in Brazil is done before bagging, but the success of this technique depends on maintaining the initial temperature of bagged seeds to safe levels (Demito and Afonso, 2009).

The aim of this study was to evaluate the physiological quality of soybean seeds artificially cooled by a dynamic process and stored in an environment without temperature control and relative humidity.

\section{Materials and Methods}

The experiment was conducted in April 2009, at the Sementes Campo Verde Ltda. company, in Campo Verde, MT. Two seed lots were used, from each of the soybean cultivars Monsoy 8757, TMG 115 RR and BRS Valiosa RR, one with cooled seeds and another with uncooled seeds. Each lot consisted of 360 bags weighing $40 \mathrm{~kg}$, with dimensions $17 \mathrm{x}$ $40 \times 70 \mathrm{~cm}$, in 30 layers of 12 bags each. Paper bags had three layers of Kraft paper with micro pores.

The seeds benefited from pre-cleaning, dryer, cleaning machine, sorting by size in $6.5 \mathrm{~mm}$ sieve, spiral machine, densimetric table and dynamic process cooling, with four circuits cooler and total power of $130 \mathrm{~kW}$ Cool Seed PCS 80 (Cool Seed Ltda., Santa Teresa do Oeste, PR, Brazil). The cooling boxes had a maximum static capacity of 19 and 11 tons each. The air reached the seed mass with a temperature of $12{ }^{\circ} \mathrm{C}$, and cooled seeds reached $18{ }^{\circ} \mathrm{C}$ during bagging. In uncooled lots, the seeds were bagged at approximately $23{ }^{\circ} \mathrm{C}$ and stored in a brick warehouse with cemented floor of $100 \mathrm{~m} \mathrm{x} 18 \mathrm{~m}$ and ceiling height of $6.5 \mathrm{~m}$, with wind hoods for air circulation.

The experiment was conducted with nine experimental units (bags) per seed lot, cooled and uncooled, totaling 18 bags per cultivar. The nine bags of each treatment were placed in three positions of the lot - basal, middle and upper - and three bags were placed in each position, spaced by six layers of bags, totaling 54 experimental units. The experimental design was completely randomized with three factors, cooling, position in the lot and storage period. The parcel corresponding to the cooling factor, the subparcel to the storage period factor and bags correspond to repetitions. Statistical analysis was 
performed individually by cultivar.

Seed samples were collected by bag, in a volume corresponding to $1.0 \mathrm{~kg}$ of seeds, after 0,60 and 120 days of storage with a metal grain trier of $24 \mathrm{~cm}$ in length, totaling 54 samples per storage period. The water content of each sample was measured with a Gehaka G 800 equipment (Gehaka Ltda., São Paulo, SP, Brazil), at the time of collection, with two replicates per sample. Per bag, $1.5 \mathrm{~kg}$ of seeds were collected, which were placed in paper boxes of $9 \times 9 \times 18 \mathrm{~cm}$, for submission to the Laboratory of Seed Research of Department of Plant Science from the Federal University of Viçosa.

For the germination test, four subsamples with 50 seeds, of each experimental unit, were distributed on a roll of towel paper, moistened with water in the ratio of 2.5 times the weight of the dry paper and kept in the germinator at $25^{\circ} \mathrm{C}$. Evaluations were performed at five and eight days after installation of the test by counting normal and abnormal seedlings and dead seeds (Brasil, 2009).

For the determination of the speed emergence index and seedling emergence in sand, four replicates with 50 seeds of each experimental unit in each storage period were sown in plastic trays with medium texture sterile sand, with $35 \mathrm{~cm}$ long and $3 \mathrm{~cm}$ deep furrows. The trays were kept in a greenhouse for 15 days, with temperatures ranging from $15{ }^{\circ} \mathrm{C}$ to $35^{\circ} \mathrm{C}$. The number of seedlings was counted from the emergence of the first seedling to the final assessment at 15 days after sowing, the results being reported in percentage. The emergence speed index (ESI) was calculated according to Maguire (1962). At the end, normal and abnormal seedlings were evaluated according to the criteria of Rules for Seed Testing (Brasil, 2009). In this test, seedling vigor was also assessed visually, considering their growth uniformity. Grades on a scale of one to five were given, where the set of more vigorous seedlings received grade one and the set of less vigorous seedlings received grade five.

For each treatment, an accelerated aging test was performed with 200 seeds distributed in plastic gerboxes with horizontal wire mesh in the middle position on a layer of $40 \mathrm{~mL}$ of distilled water. The boxes were placed in BOD incubator at $41{ }^{\circ} \mathrm{C}$, where they remained for 48 hours (Association of Official Seed Analysts, 1983; Krzyzanowski et al., 1991; Marcos-Filho, 1999). After this period, four subsamples with 50 seeds each were subjected to the germination test, a counting being conducted at five days, when normal, abnormal and dead seeds seedlings were computed according to Brasil (2009).

In order to determine electrical conductivity, two subsamples, each with 50 seeds per experimental unit, were weighed in balance with a resolution of $0.001 \mathrm{~g}$, placed in plastic cups with $75 \mathrm{~mL}$ of distilled water, and taken to the BOD incubator at $25{ }^{\circ} \mathrm{C}$ for 24 hours. After this period, the electrical conductivity was obtained in the soaking solution with Digimed CD-21 conductivity meter. The results were expressed in $\mu \mathrm{S} . \mathrm{cm}^{-1} \cdot \mathrm{g}^{-1}$ of seeds (AOSA, 1983; Vieira and Krzyzanowski, 1999).

For the tetrazolium test, two subsamples with 50 seeds of each experimental unit were pre-moistened between germination paper, during 16 hours at $25{ }^{\circ} \mathrm{C}$, being then immersed in tetrazolium solution at $0.075 \%$ and maintained for three hours at $35{ }^{\circ} \mathrm{C}$ in absence of light. After this period, the seeds were washed in running water and vigor and seed viability were assessed according to the methodology established by França-Neto (1999).

Statistical analysis was performed with SAS software, version 9.0. Data in percentages were previously transformed into $\arcsin$ of the root of $x / 100$, where $x$ is the value in percentage and means compared by Tukey test were $0.05 \%$. The presentation of the results was made with the average of the original data.

\section{Results and Discussion}

For the Monsoy 8757 cultivar (Table 1), the water content of the cooled seeds was lower in the initial storage, but increased in the first 60 days and decreased $0.9 \%$ during the period from 60 to 120 days of storage. This variation is related to a reduction of $22.9 \%$ in air RH from June through August (Figure 1). According to Cardoso et al. (2004) the average decrease of $0.6 \%$ in the moisture content of seeds per month of storage did not decrease the deterioration of soybean seeds. On the other hand, Moreira (1994) and Demito and Afonso (2009) reported that cooling may decrease the water content in the seeds and this may contribute to slow the deterioration process of soybean seeds.

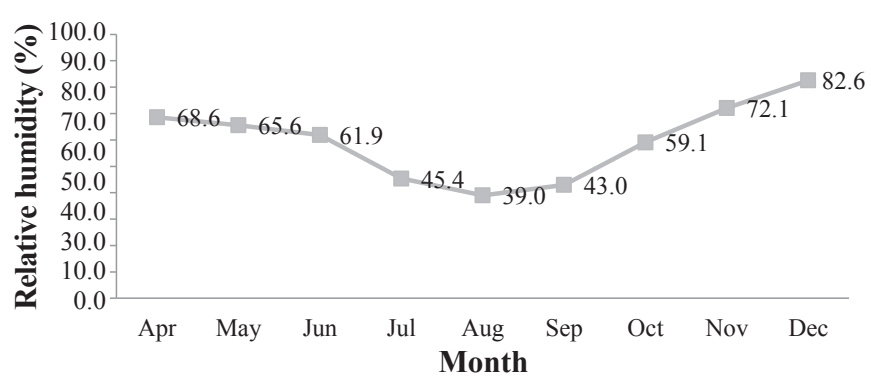

Figure 1. Monthly air relative humidity (RH) of the warehouse in Campo Verde, MT, 2009.

The viability determined by the tetrazolium test of soybean seeds cultivar Monsoy 8757 (Table 1) was raised during execution of the trial, with values always higher than $96 \%$ during storage. Some variations were observed between 
the treatments, however, in the overall average, no differences were observed between the results obtained for the cooled and uncooled lots. The same can be said for the vigor given by the same test. The result of germination in the final assessment was significantly higher in the refrigerated treatment. The emergence in sand was approximately $4 \%$ higher for the cooled lot at 120 days of storage. The artificial cooling kept the seed quality of corn and soybean seeds during storage (Carvalho and Silva, 1994), but the soybean seeds lose their viability after 120 days of storage at simulated tropical conditions (Estevão, 2002). In this same sense, Cardoso et al. (2004) reported that soybean seeds with an initial moisture content of $14 \%$ and stored at the top of the stack, on cold aeration system, had lower vigor after two months of storage.

Table 1. Mean values obtained for seed water content and physiological quality tests during storage of soybean cultivar Monsoy 8757 , cooled and uncooled.

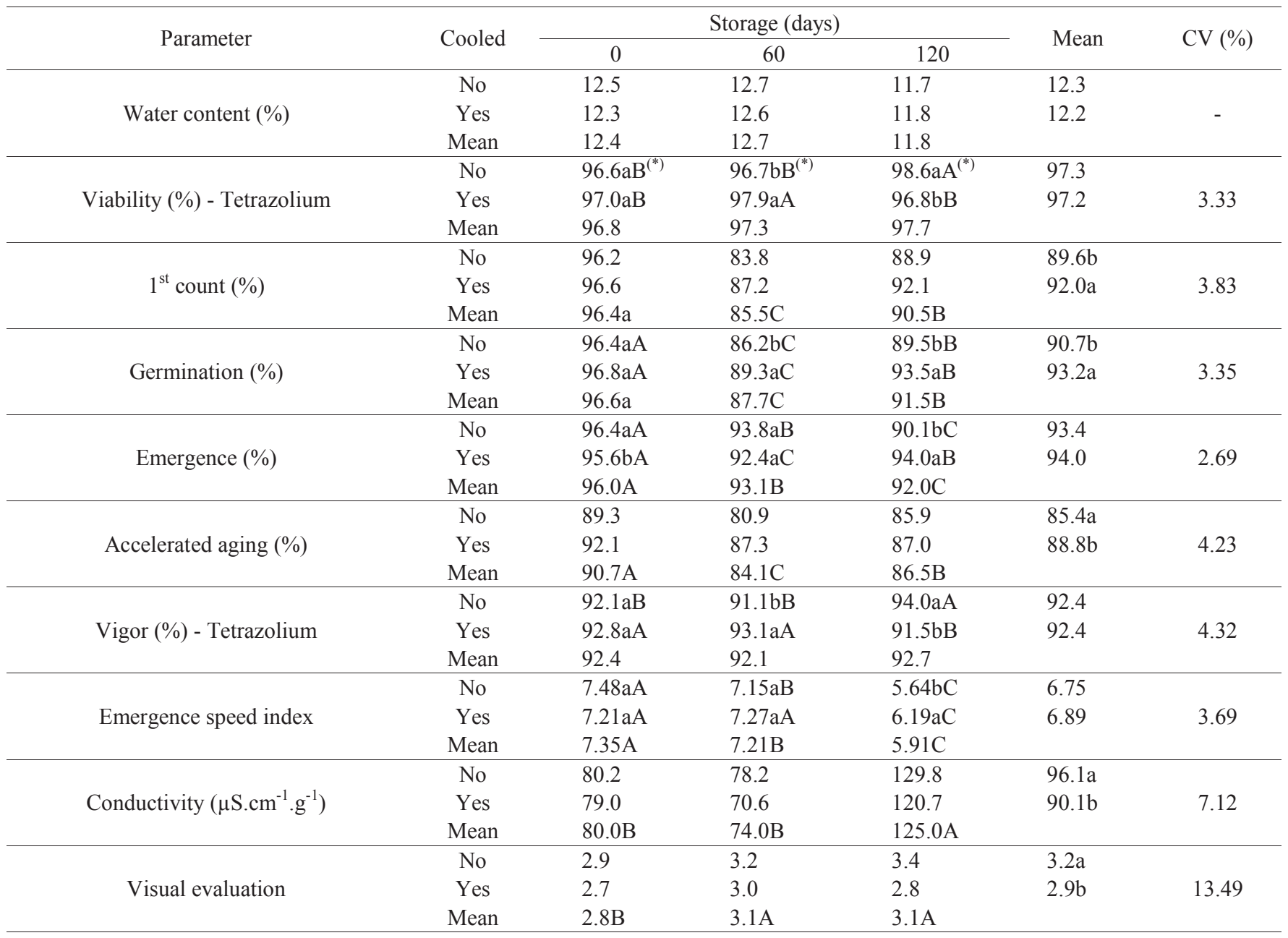

${ }^{(*)}$ For each variable, means followed by the same letters, uppercase in rows and lowercase letters in columns, do not differ by Tukey’s test at $5 \%$ probability.

In the accelerated aging test (Table 1), seeds in the cooled lot had germination $3.4 \%$ higher than those uncooled, and this difference was higher at 60 days of storage $(6.4 \%)$. The emergence speed index of cooled seeds was higher than the uncooled at 120 days of storage and showed a reduction in seed quality over storage time for both treatments. The cooled seeds had lower leaching of solutes in the electrical conductivity test, which indicates a better organization of the membranes system of cooled seeds. The quality of artificially cooled seeds was also better in the visual assessment of seedlings, in the emergence in sand test. The best quality of cooled seeds, over storage, can be related to the lower temperature of the seed mass in the first 15 days of storage (Figure 2A). It has been observed that the temperature affects the leaching of solutes in soybean seeds (Vieira et al., 2008; Fessel et al., 2010). However, there is no direct relationship between the leaching of solutes and the content of fatty acids and carbohydrates in seeds (Panobianco and Vieira, 2007). 


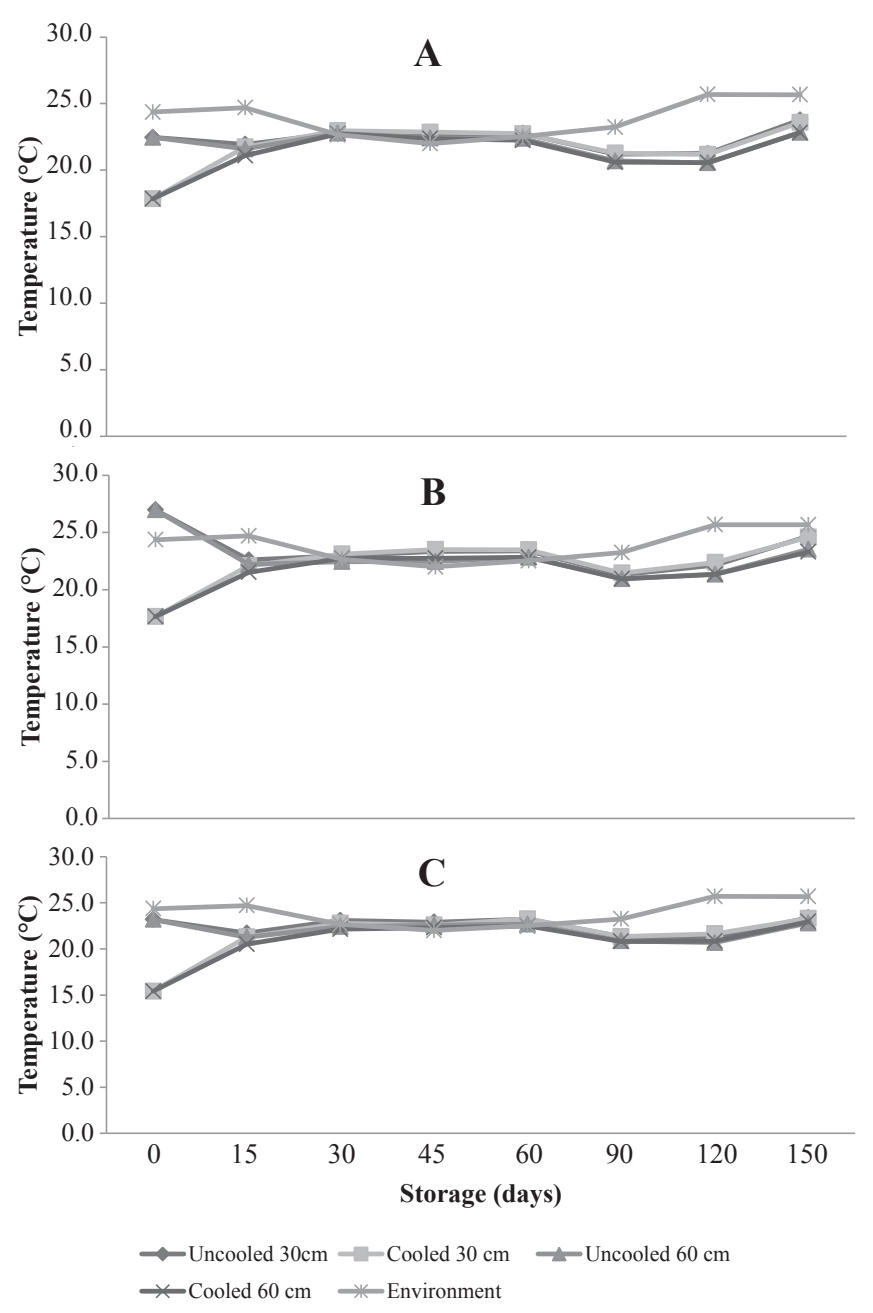

Figure 2. Temperature of the mass of soybean cultivars Monsoy 8757 (A); TMG 115 RR (B) and BRS Valiosa RR (C), of cooled and uncooled lots, at 30 and $60 \mathrm{~cm}$ depth in bags and internal environment of the warehouse, for 150 days.

In cultivar TMG 115 RR (Table 2), it was also observed that the water content decreased from $12.1 \%$ to $11.0 \%$, from 60 to 120 days of storage. Seed viability determined by the tetrazolium was high throughout the storage period and, although the uncooled lot has had a viability $1.5 \%$ higher than the cooled lot, it can be said that viability was not affected by the seed cooling before its storage. The emergence in sand was $5.4 \%$ higher in seeds of the cooled lot at 120 days, but germination in the accelerated aging test did not differ between cooled and uncooled seeds. However, this test accurately detected the deterioration of seeds, cooled or not, during the storage period, as evidenced by the significant reduction in their values from $83.3 \%$ to $69.9 \%$ from 0 to 120 days of storage. According to Cunha et al. (2009), the deterioration can be intensified by extending the storage period, even under refrigeration, or, according to Dan et al. (2010), with no temperature control.

Still for cultivar TMG 115 RR, by the evaluations of the emergence speed index, electrical conductivity and by visual assessment of the seedlings (Table 2) superior seeds are observed in the cooled lot during storage, compared to the uncooled lot. Again, the higher quality of cooled seeds is attributed to the lower temperature of the seeds in the first 15 days of storage (Figure 2B).

The water content of the BRS Valiosa RR cultivar (Table 3) varied as for Monsoy 8757 and TMG 115 RR, with a decrease between 60 and 120 days of storage. The viability, the first and last germination counts, emergence in sand, vigor by tetrazolium and germination in the accelerated aging remained at high levels in the cooled or uncooled seeds during the entire storage period. This indicates that the seeds of this cultivar have good storability. In assessing the visual aspect of emerged seedlings in the sand test, the cooled seeds had higher vigor.

The results concerning the viability, germination in accelerated aging test and leaching of solutes (Table 3) were statistically higher in uncooled seeds, despite the numerical differences being of little significance. This indicates that, differently from the two cultivars previously reported, although the temperature of cooled seed mass is lower in the first 15 days of storage (Figure 2C), that did not promote a higher quality for the BRS Valiosa RR cultivar. This was probably due to the higher quality of uncooled seeds at the beginning of storage.

An important fact that should be emphasized in this work is that the temperature of the cooled seeds of the three cultivars studied here remained lower than uncooled seeds only during the first 15 days. This fact, coupled with the initial quality aspects of the seeds exposed above, may explain the small improvement in maintaining the quality of the seeds of the Monsoy 8757 and TMG 115 RR cultivars and the lack of response to the cooling treatment for the BRS Valiosa RR cultivar. It is suggested that additional investigations are performed with the use of a dynamic seed cooling system, while maintaining the seeds in cold storage throughout the storage period. 
Table 2. Mean values obtained for water content and physiological quality tests during storage of soybean cultivar TMG 115 $\mathrm{RR}$, cooled and uncooled.

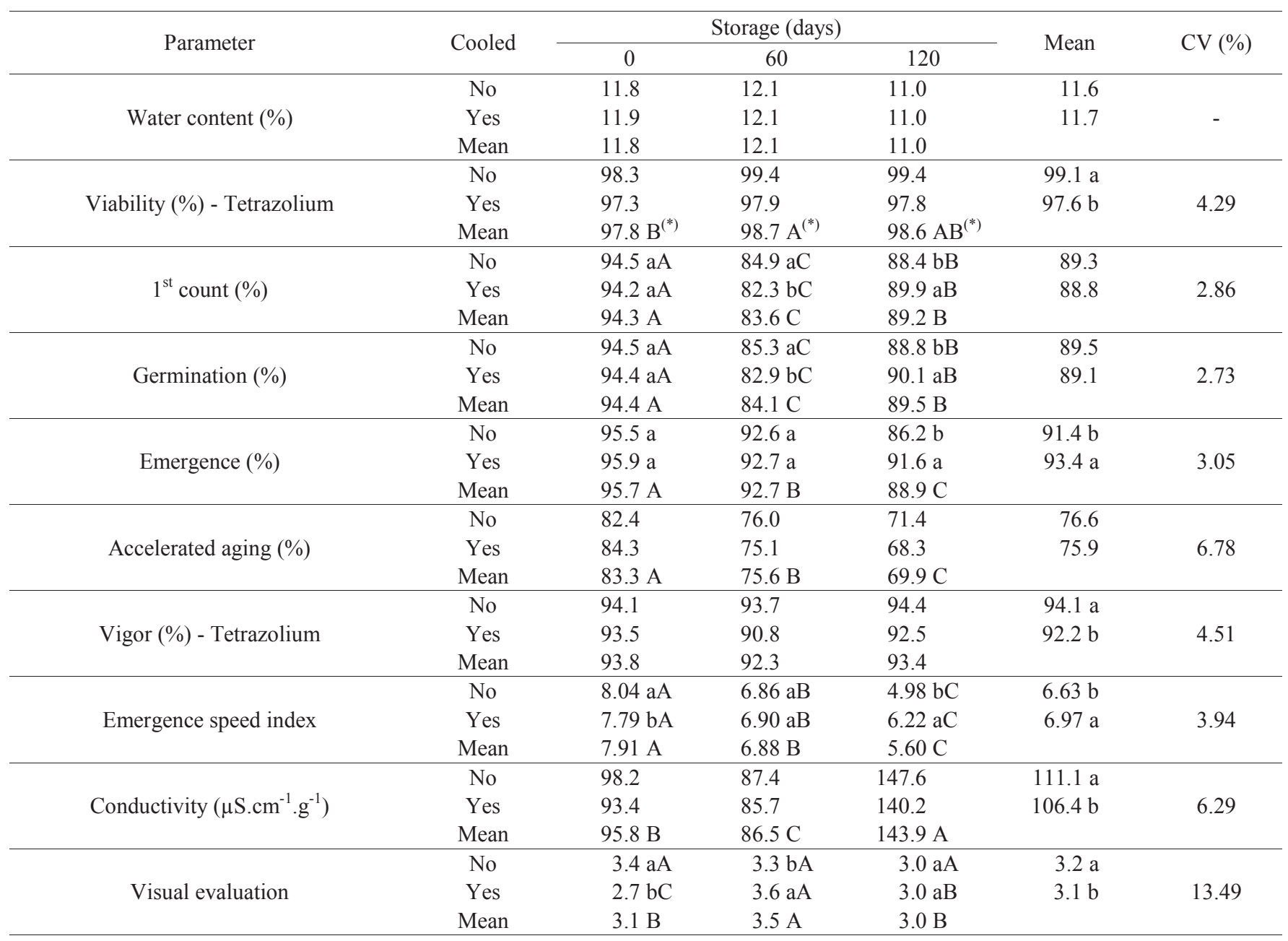

${ }^{(*)}$ For each variable, means followed by the same letters, uppercase in rows and lowercase letters in columns, do not differ by Tukey's test at $5 \%$ probability. 
Table 3. Mean values obtained for water content and physiological quality tests during storage of soybean cultivar, cooled and uncooled.

\begin{tabular}{|c|c|c|c|c|c|c|}
\hline \multirow{2}{*}{ Parameter } & \multirow{2}{*}{ Cooled } & \multicolumn{3}{|c|}{ Storage (days) } & \multirow{2}{*}{ Mean } & \multirow{2}{*}{ CV $(\%)$} \\
\hline & & 0 & 60 & 120 & & \\
\hline \multirow{3}{*}{ Water content $(\%)$} & No & 11.6 & 12.0 & 11.5 & 11.7 & \\
\hline & Yes & 11.7 & 11.9 & 11.4 & 11.6 & - \\
\hline & Mean & 11.6 & 11.9 & 11.4 & & \\
\hline \multirow{3}{*}{ Viability (\%) - Tetrazolium } & No & 97.0 & 98.1 & 98.1 & $97.7 \mathrm{a}$ & \\
\hline & Yes & 96.8 & 96.8 & 97.4 & $97.0 \mathrm{~b}$ & 4.56 \\
\hline & Mean & 96.9 & 97.5 & 97.7 & & \\
\hline \multirow{3}{*}{$1^{\text {st }} \operatorname{count}(\%)$} & No & 97.9 & 94.4 & 97.2 & 96.5 & \\
\hline & Yes & 97.6 & 94.9 & 97.2 & 96.6 & 3.4 \\
\hline & Mean & $97.7 \mathrm{~A}^{(*)}$ & $94.7 \mathrm{~B}^{(*)}$ & $97.2 \mathrm{~A}^{(*)}$ & & \\
\hline \multirow{3}{*}{ Germination (\%) } & No & 98.0 & 94.8 & 97.2 & 96.7 & \\
\hline & Yes & 97.7 & 95.6 & 97.3 & 96.9 & 3.46 \\
\hline & Mean & $97.9 \mathrm{~A}$ & $95.2 \mathrm{~B}$ & $97.2 \mathrm{~A}$ & & \\
\hline \multirow{3}{*}{ Emergence (\%) } & No & 96.8 & 96.8 & 97.2 & 96.9 & \\
\hline & Yes & 96.3 & 97.0 & 97.2 & 96.9 & 3.01 \\
\hline & Mean & 96.6 & 96.9 & 97.2 & & \\
\hline \multirow{3}{*}{ Accelerated aging $(\%)$} & No & 93.6 & 93.7 & 94.4 & $93.9 \mathrm{a}$ & \\
\hline & Yes & 92.0 & 93.0 & 93.3 & $92.8 \mathrm{~b}$ & 2.66 \\
\hline & Mean & 92.8 & 93.4 & 93.8 & & \\
\hline \multirow{3}{*}{ Vigor (\%) - Tetrazolium } & No & 94.5 & 94.6 & 94.7 & 94.6 & \\
\hline & Yes & 92.7 & 93.8 & 94.9 & 93.8 & 5.02 \\
\hline & Mean & 93.6 & 94.2 & 94.8 & & \\
\hline \multirow{3}{*}{ Emergence speed index } & No & $8.22 \mathrm{bA}$ & $8.11 \mathrm{aB}$ & $7.76 \mathrm{aC}$ & 8.03 & \\
\hline & Yes & $8.62 \mathrm{aA}$ & $7.91 \mathrm{bB}$ & $7.78 \mathrm{aC}$ & 8.10 & 4.02 \\
\hline & Mean & $8.42 \mathrm{~A}$ & $8.01 \mathrm{~B}$ & $7.77 \mathrm{C}$ & & \\
\hline \multirow{3}{*}{ Conductivity $\left(\mu \mathrm{S} \cdot \mathrm{cm}^{-1} \cdot \mathrm{g}^{-1}\right)$} & No & $57.3 \mathrm{aB}$ & $51.3 \mathrm{aC}$ & $79.7 \mathrm{bA}$ & $62.8 \mathrm{~b}$ & \\
\hline & Yes & $57.4 \mathrm{aB}$ & $52.6 \mathrm{aC}$ & $83.8 \mathrm{aA}$ & $64.6 \mathrm{a}$ & 6.29 \\
\hline & Mean & $57.4 \mathrm{~B}$ & $52.0 \mathrm{C}$ & $81.8 \mathrm{~A}$ & & \\
\hline \multirow{3}{*}{ Visual evaluation } & No & 1.2 & 2.7 & 2.9 & $2.2 \mathrm{a}$ & \\
\hline & Yes & 1.2 & 2.3 & 2.1 & $1.9 \mathrm{~b}$ & 23.67 \\
\hline & Mean & $1.2 \mathrm{~B}$ & $2.5 \mathrm{~A}$ & $2.5 \mathrm{~A}$ & & \\
\hline
\end{tabular}

${ }^{(*)}$ For each variable, means followed by the same letters, uppercase in rows and lowercase letters in columns, do not differ by Tukey's test at $5 \%$ probability.

\section{Conclusions}

Soybean seeds artificially cooled by the dynamic method has physiological potential superior to uncooled seeds during storage under uncontrolled conditions. However, for seed lots of high physiological quality, this higher performance might not be observed.

\section{References}

ASSOCIATION OF OFFICIAL SEED ANALYSTS. Seed vigor testing handbook. Contribution No. 32 to the Handbook on Seed Testing. Stillwater: AOSA, 1983. 93p.

BRAGANTINI, C. Alguns aspectos do armazenamento de sementes e grãos de feijão. Santo Antônio de Goiás: Embrapa Arroz e Feijão, 2005. 28p. (Embrapa Arroz e Feijão. Documentos, 187).
BRASIL. Ministério da Agricultura, Pecuária e Abastecimento. Regras para análise de sementes. Ministério da Agricultura, Pecuária e Abastecimento. Secretaria de Defesa Agropecuária. Brasília: MAPA/ACS, 2009. 395p. http:// www.bs.cca.ufsc.br/publicacoes/regras\%20analise\%20sementes.pdf

CARDOSO, P.C.; BAUDET, L.; PESKE, S.T.; LUCCA-FILHO, O.A. Armazenamento em sistema a frio de sementes de soja tratadas com fungicida. Revista Brasileira de Sementes, v.26, n.1, p.15-23, 2004. http:// www.scielo.br/pdf/rbs/v26n1/a03v26n1.pdf

CARVALHO, M.L.M.; SILVA, W.R. Refrigeração e qualidade de sementes de milho armazenadas em pilhas com diferentes embalagens. Pesquisa Agropecuária Brasileira, v.9, p.1319-1332, 1994. http://orton.catie.ac.cr/cgi-bin/wxis.exe/?IsisScript=ACERVO. xis \&method $=$ post $\&$ formato $=2 \&$ cantidad $=1 \&$ expresion $=m f n=052804$

CARVALHO, N.M.; NAKAGAWA, J. Sementes: ciência, tecnologia e produção. 4. ed. Jaboticabal: FUNEP, 2000. 588 p.

CUNHA, J.P.A.R.; OLIVEIRA, P.; SANTOS, C.M.; MION, R.L. Qualidade das sementes de soja após a colheita com dois tipos de colhedora e dois períodos de armazenamento. Ciência Rural, v.39, n.5, p.1420-1425, 2009. http://www.scielo.br/pdf/cr/v39n5/a169cr286.pdf 
DAN, L.G.M.; DAN, H.A.; BARROSO, A.L.L.; BRACCINI, A.L. Qualidade fisiológica de sementes de soja tratadas com inseticidas sob efeito do armazenamento. Revista Brasileira de Sementes, v.32, n.2, p.131-139, 2010. http://www.scielo.br/pdf/rbs/v32n2/v32n2a16.pdf

DEMITO, A.; AFONSO, A.D.L. Qualidade das sementes de soja resfriadas artificialmente. Engenharia na Agricultura, v.17, p.7-14, 2009. http://www. seer.ufv.br/seer/index.php/reveng/article/viewFile/88/41

ESTEVÃO, C.P. Qualidades fisiológica e sanitária de sementes de soja tratadas e armazenadas em diferentes ambientes. Scientia Agraria, v.3, p.113113, 2002. http://ojs.c3sl.ufpr.br/ojs2/index.php/agraria/article/view/1040

FERREIRA, G.F.; BORGUETTI, F. Germinação: do básico ao aplicado. São Paulo: Artmed, 2004. 323p.

FESSEL, S.A.; PANOBIANCO, M.; SOUZA, C.R.; VIEIRA, R.D. Teste de condutividade elétrica em sementes de soja armazenadas sob diferentes temperaturas. Bragantia, v.69, p.207-214, 2010. http://www.scielo.br/pdf/ brag/v69n1/26.pdf

FRANÇA-NETO, J.B. Teste de tetrazólio para determinação do vigor de sementes. In: KRZYZANOWSKI, F.C.; VIEIRA, R.D.; FRANÇA-NETO, J.B. (Ed.). Vigor de sementes: conceitos e testes. Londrina: ABRATES, 1999. p.8.18.7.

FRANÇA-NETO, J. B.; KRZYZANOWSKI, F. C.; COSTA, N. P. O teste de tetrazólio em sementes de soja. Londrina: EMBRAPA-CNPSoja, 1998. 72p. (EMBRAPA-CNPSo. Documentos, 116).

HARRINGTON, J.F. Thumb rules of drying seeds. Crops \& Soils, v.13, n.1, p.16-17. 1960.

KRZYZANOWSKI, F.C.; FRANÇA-NETO, J.B.; HENNING, A.A. Relato dos testes de vigor disponíveis para as grandes culturas. Informativo ABRATES, v.1, p.15-50, 1991.
MAGUIRE, J.D. Speed of germination-aid in selection and evaluation for seedling emergence and vigor. Crop Science, v.2, p.176-177, 1962. http://scholar.google.com.br/scholar?q=Speed $\% 20$ of $\% 20$ germinationaid $\% 20$ in $\% 20$ selection $\% 20$ and $\% 20$ evaluation $\% 20$ for $\% 20$ seedling $\% 20$ emergence\%20and\%20vigor

MARCOS FILHO, J. Teste de envelhecimento acelerado. In: KRZYZANOWSKI, F.C.; VIEIRA, R.D.; FRANÇA-NETO, J.B. (Ed.). Vigor de sementes: conceitos e testes. Londrina: ABRATES, 1999. p.3.1-3.24.

MOREANO, T.B.; BRACCINI, A.L.; SCAPIM, C.A.; KRZYZANOWSKI, F.C.; FRANÇA-NETO, J.B.; MARQUES, O.J. Changes in the effects of weathering and mechanical damage on soybean seed during storage. Seed Science and Technology, v.39, p.604-611. 2011.

MOREIRA, R.G. Aeração de grãos usando ar natural e frio. In: INTERNATIONAL SYMPOSIUM ON GRAIN CONSERVATION, 1993, Canela. Anais. Porto Alegre: Plus Comunicações, 1994. p.177-196.

PANOBIANCO, M.; VIEIRA, R.D. Condutividade elétrica e deterioração de sementes de soja submetidas a diferentes condições de armazenamento. Revista Brasileira de Sementes, v.29, p.97-105, 2007. http://www.scielo.br/ pdf/rbs/v29n2/v29n2a13.pdf

POPINIGIS, F. Fisiologia da semente. 2. ed., Brasília: AGIPLAN, 1985. 289p.

VIEIRA, R.D.; KRZYZANOWSKI, F.C. Teste de condutividade elétrica. In: KRZYZANOWSKI, F.C.; VIEIRA, R.D.; FRANÇA-NETO, J.B. (Ed.) Vigor em sementes: conceitos e testes. Londrina. ABRATES. 1999. p.4,1-4-26.

VIEIRA，R.D.; TEKRONY，D.M.; EGLI，D.B.; BRUENNING，W.P.; PANOBIANCO, M. Temperatura de armazenamento e quantidade de lixiviados na solução de embebição de sementes de soja. Scientia Agricola, v.65, p.496-501, 2008. http://www.scielo.br/pdf/sa/v65n5/a08v65n5.pdf 